\title{
ANALISIS KINERJA KETAHANAN TEKAN LINGKAR SEBAGAI PARAMETER MUTU KERTAS LAINER DAN MEDIUM
}

\author{
Taufan Hidayat \\ Balai Besar Pulp dan Kertas \\ Jl. Raya Dayeuhkolot 132 Bandung 40258, Telp +62225202980, Fax +62225202871 \\ taufanhidayat@gmail.com \\ Diterima : 02 Maret 2012, Revisi akhir : 30 Mei 2012
}

\section{PERFORMANCE ANALYSIS OF RING CRUSH TEST AS QUALITY PARAMETER OF LINER AND FLUTING MEDIUM}

\begin{abstract}
There are some trends happen in relation to corrugating industries, namely the substitution of liner by fluting medium for certain corrugated container which do not need strength tightly. Due to the tremendous usage of this box type, the requirements of stacking strength (BCT) of the box neglected following by the ignoring of ring crush test (RCT) value for liner and medium. The RCT easily neglected due to the facts that this parameter do not successful to correlate well with the BCT. The results of testing analysis for a number of liner and medium samples coming from Indonesian paper mill supported these facts. The RCT is not a material property of liner and medium, the value depends on basis weight and manufacturing processes. Short-span Compression Test (SCT) was proven covering the weaknesses of $R C T$, therefore the SCT is proposed to replace the RCT.
\end{abstract}

Keywords: RCT, SCT, material-property, liner, medium fluting

\section{ABSTRAK}

Telah terjadi kecenderungan substitusi kertas lainer oleh kertas medium di industri kotak karton gelombang untuk keperluan tertentu yang tidak memerlukan kekuatan secara ketat. Tetapi karena penggunaan jenis kotak seperti ini sangat banyak, maka persyaratan ketahanan tumpuk (BCT) kotak menjadi terabaikan diikuti dengan terbaikannya nilai ketahanan tekan lingkar (RCT) lainer dan medium. Mudahnya RCT diabaikan karena fakta menunjukkan bahwa RCT tidak mampu memprediksi BCT dengan baik. Hasil analisis pengujian kertas lainer dan medium dari pabrik-pabrik di Indonesia mendukung fakta tersebut. RCT bukan karakter bahan lainer dan medium, nilainya sangat tergantung pada gramatur dan proses manufaktur. Sementara itu parameter SCT telah terbukti mampu mengatasi kekurangan RCT, maka diusulkan agar SCT menjadi parameter baru pengganti RCT.

Kata kunci: RCT, SCT, karakter-bahan, lainer, medium

\section{PENDAHULUAN}

Dalam beberapa tahun terakhir ini ada gejala menarik terkait dengan spesifikasi kertas lainer dan medium. Adanya kebutuhan terhadap kotak karton gelombang (KKG) dengan mutu minimalis, untuk keperluan pengemasan barang yang nilainya juga tidak terlalu mahal seperti mie instan, maka berkembanglah penggunaan kertas medium sebagai pengganti kertas lainer. Untuk kemasan seperti ini, struktur karton gelombang $(\mathrm{KG})$ dinding tunggal yang seharusnya lainer-medium-lainer, maka sekarang menjadi medium-medium-medium. Sebenarnya substitusi semacam ini akan menurunkan kualitas $\mathrm{KKG}$, sebagaimana telah dipaparkan dalam tulisan terdahulu (Hidayat, dkk., 2008). Tetapi penggunaan $\mathrm{KG}$ seperti ini terus meningkat jumlah maupun jenis barang yang dikemasnya, yang pada pokoknya adalah bila diperlukan KKG dengan harga terjangkau, maka dapat dipastikan jenis KKG seperti inilah yang akan ditawarkan. Dengan demikian sekarang struktur ini menjadi semacam "jenis baru" dari KG dan KKG yang 
belum tercakup dalam standar spesifikasi $\mathrm{KG}$ maupun KKG yang sudah ada.

Gejala berikutnya terkait dengan kertas lainer dan medium adalah adanya pengabaian parameter ketahanan tekan lingkar (Ring Crush Test, RCT) baik oleh produsen maupun konverter. Sifat kertas lainer yang lebih diutamakan adalah ketahanan retak, sedangkan untuk kertas medium ketahanan tekan datar (Concora Medium Test, CMT). Pada saat tulisan ini dibuat, sedang dilakukan revisi SNI spesifikasi kertas lainer dan medium.Hasil survei ke produsen maupun konverter dalam rangka revisi tersebut semakin mempertegas adanya keinginan para pemangku kepentingan untuk mengabaikan parameter RCT dalam spesifikasi kertas lainer dan medium. Hal ini tentu saja sangat bertentangan dengan hasil kajian ilmiah yang menunjukkan bahwa kualitas KKG turut ditentukan oleh nilai RCT komponen lainer dan medium (Laakso dan Rintamäki, 2001).

Diduga, pengabaian tersebut di atas terjadi karena ada ketidakpuasan terhadap kinerja RCT sebagai parameter mutu kertas lainer dan medium. Nilai RCT sulit dikorelasikan dengan mutu lainer dan medium, dengan kata lain sulit memprediksi mutu lainer dan medium dari parameter RCT (Dimitrov, 2010). Hal ini bisa terjadi jika RCT tidak merupakan karakter bahan (material property) dari kertas lainer dan medium. Suatu parameter dikatakan sebagai karakter bahan jika besaran nilai parameter tersebut tidak tergantung pada gramatur (Gullischen dan Paulapuro, 1999 Book 16). Contoh parameter kertas lainer yang merupakan karakter bahan adalah indeks retak. Hal ini telah dibuktikan pada tulisan terdahulu dengan menggunakan contoh uji kertas lainer (Hidayat, 2009). Ini pula sebabnya mengapa saat ini parameter indeks retak lebih disukai digunakan untuk kertas lainer daripada RCT. Beberapa ulasan penulis terdahulu menyiratkan bahwa ada kemungkinan RCT itu bukan karakter bahan karena nilai RCT pada gramatur rendah akan sangat berbeda dengan nilai RCT pada gramatur tinggi (Replogle, 2001). Sementara itu analisis lain juga menunjukkan bahwa penyimpangan linieritas nilai RCT semakin besar dengan meningkatnya gramatur (Popil, 2010).

RCT banyak digunakan oleh kalangan produsen maupun konverter karena kesederhanaan aksesori alat ujinya dan metodenya sesuai untuk kertas lainer dan medium (Laakso dan Rintamäki, 2001). Di kalangan akademisi dan peneliti, parameter
RCT juga masih digunakan sebagai variabel respon dari penelitiannya. Sebagai contoh, hasil pengamatan menunjukkan adanya peningkatan nilai RCT dengan membesarnya intensitas penggilingan pulp semikimia (Samariha, dkk., 2011). Sementara penelitian lain menyimpulkan bahwa nilai RCT bertambah dengan menurunnya rendemen proses pembuatan pulp (Khaki, dkk., 2011). Buku standar teknologi kertas, juga masih merekomendasikan penggunaan RCT sebagai parameter ketahanan tekan kertas lainer (Holik, 2006), bahkan nilai RCT dijadikan sebagai parameter pembeda antara Kraft Liner dan Test Liner (Anonymous, 2007).

Melihat kecenderungan yang terjadi di masyarakat terkait dengan substitusi kertas lainer oleh kertas medium dan pengabaian nilai RCT sebagai parameter mutu kertas lainer dan medium, termasuk pro-kontra parameter RCT sebagai karakter bahan, maka dalam tulisan ini akan dilakukan analisis terhadap sejumlah contoh uji kertas lainer dan medium yang berasal dari sejumlah pabrik di Indonesia. Analisis ditujukan pada pemeriksaan nilai RCT sebagai karakter bahan, meliputi pembahasan parameter ketahanan tekan untuk jenis kertas lainer dan medium yang berbeda dalam satu pabrik (within mill), serta pada jenis lainer dan medium yang sama antar pabrik yang berbeda (between mill).

\section{BAHAN DAN METODE}

Bahan berupa contoh uji dikumpulkan dari sejumlah pabrik kertas lainer dan medium di Indonesia. Untuk menjaga privasi, nama pabrik yang bersangkutan disamarkan, dan diperoleh contoh uji seperti disajikan pada Tabel 1.

Tabel 1. Contoh Uji Kertas Lainer dan Medium

\begin{tabular}{ccc}
\hline \multirow{2}{*}{ Pabrik } & \multicolumn{2}{c}{$\operatorname{GSM}\left(\mathrm{g} / \mathrm{m}^{2}\right)$} \\
\cline { 2 - 3 } & Lainer & Medium \\
\hline A & $200,275,300,450$ & $125,200,250$ \\
B & $125,150,200$ & $112,125,150$ \\
C & $125,150,200,275$ & 125 \\
D & $125,150,200$ & $112,125,250$ \\
E & $125,150,200,275$ & $112,125,150$ \\
F & $125,150,200$ & 125,150 \\
G & - & 125 \\
\hline
\end{tabular}

Terhadap contoh kertas lainer dan medium tersebut, dilakukan pengujian RCT menggunakan alat uji RCT jenis pelat lentur (T818 cm-07). 
Pengujian dilakukan pada contoh arah mesin (AM) dan silang mesin (SM). Selanjutnya dilakukan perhitungan indeks tekan dalam $\mathrm{Nm} / \mathrm{g}$ dengan cara membagi nilai ketahanan tekan $(\mathrm{N} / \mathrm{m})$ oleh gramatur $\left(\mathrm{g} / \mathrm{m}^{2}\right)$. Hasil perhitungan nilai indeks tekan dievaluasi ketergantungannya terhadap gramatur. Evaluasi dilakukan pada jenis lainer medium yang berbeda dalam satu pabrik (within mill), untuk mengantisipasi keragaman jenis pada proses manufaktur yang sama. Juga dilakukan evaluasi pada jenis yang sama tapi dibuat oleh pabrik yang berbeda (between mill), untuk mengantisipasi keragaman proses manufaktur pada jenis yang sama.

Jika diperoleh nilai indeks tekan yang konstan pada berbagai gramatur dalam pabrik yang sama, atau pada antar pabrik yang berbeda pada gramatur yang sama, mengindikasikan bahwa parameter RCT adalah karakter bahan, jika tidak, maka parameter RCT bukan merupakan karakter bahan. Selanjutnya dilakukan pengkajian metode uji SCT (Short-span Compression Test) sebagai alternatif yang lebih baik dari uji RCT.

\section{HASIL DAN PEMBAHASAN}

\section{Indeks Tekan dalam Pabrik (Within Mill)}

Tabel 2 menyajikan nilai indeks tekan berbagai jenis kertas lainer dalam pabrik yang sama untuk semua pabrik yang contoh ujinya menjadi fokus perhatian. Pembahasan indeks tekan dalam pabrik bertujuan agar meskipun proses manufaktur kertasnya sama, keragaman jenis kertas bisa teramati. Dalam Tabel 2, tinjau salah satu pabrik, misalnya Pabrik A. Nilai Indeks tekan pada kisaran gramatur $200-450$ sama sekali tidak dapat dikatakan konstan baik AM maupun SM. Perbedaan nilai terendah dan tertinggi adalah 5,17 (AM) dan 7,04 (SM). Nilai Indeks Tekan sangat tergantung pada nilai gramatur kertas lainer. Ini indikasi bahwa indeks tekan bukan karakter bahan. Untuk pabrik-pabrik yang lain pada Tabel 2, kondisinya sama saja, yaitu bahwa nilai indeks tekan tergantung pada nilai gramatur. Selanjutnya, data untuk kertas medium dapat dilihat pada Tabel 3.

Dari Tabel 3 untuk Pabrik E, kisaran gramatur adalah $112-175$. Nilai indeks tekan meningkat dengan naiknya gramatur, baik AM maupun SM. Perbedaan nilai indeks tekan terendah dan tertinggi adalah 2,98 (AM) dan 1,92 (SM). Gejala ini terjadi di semua jenis kertas medium di masing-masing pabrik. Sekali lagi data ini menunjukkan bahwa nilai indeks tekan kertas medium tergantung pada nilai gramatur.

Tabel 2. Indeks Tekan Lainer dalam Pabrik

\begin{tabular}{|c|c|c|c|}
\hline \multirow{2}{*}{ Pabrik } & \multirow{2}{*}{$\begin{array}{c}\text { GSM } \\
\left(\mathrm{g} / \mathrm{m}^{2}\right)\end{array}$} & \multicolumn{2}{|c|}{ Indeks Tekan $(\mathrm{Nm} / \mathrm{g})$} \\
\hline & & $\mathrm{AM}$ & $\mathrm{SM}$ \\
\hline \multirow{4}{*}{ A } & 200 & 27,50 & 15,80 \\
\hline & 275 & 25,37 & 19,25 \\
\hline & 300 & 23,23 & 17,40 \\
\hline & 450 & 32,67 & 22,84 \\
\hline \multirow{3}{*}{ B } & 125 & 13,32 & 12,42 \\
\hline & 150 & 16,91 & 13,91 \\
\hline & 200 & 21,46 & 17,00 \\
\hline \multirow{4}{*}{$\mathrm{C}$} & 125 & 18,43 & 13,79 \\
\hline & 150 & 20,17 & 14,58 \\
\hline & 200 & 23,81 & 18,38 \\
\hline & 275 & 27,19 & 20,43 \\
\hline \multirow{3}{*}{$\mathrm{D}$} & 125 & 13,84 & 10,35 \\
\hline & 150 & 15,45 & 11,69 \\
\hline & 200 & 18,79 & 15,13 \\
\hline \multirow{4}{*}{$\mathrm{E}$} & 125 & 7,40 & 6,04 \\
\hline & 150 & 10,05 & 7,31 \\
\hline & 200 & 12,67 & 8,79 \\
\hline & 275 & 14,73 & 9,98 \\
\hline \multirow{3}{*}{$\mathrm{F}$} & 125 & 7,42 & 5,56 \\
\hline & 150 & 9,04 & 7,02 \\
\hline & 200 & 11,49 & 8,37 \\
\hline
\end{tabular}

Tabel 3. Indeks Tekan Medium dalam Pabrik

\begin{tabular}{cccc}
\hline \multirow{2}{*}{ Pabrik } & GSM & \multicolumn{2}{c}{ Indeks Tekan $(\mathrm{Nm} / \mathrm{g})$} \\
\cline { 3 - 4 } & $\left(\mathrm{g} / \mathrm{m}^{2}\right)$ & $\mathrm{AM}$ & $\mathrm{SM}$ \\
\hline \multirow{2}{*}{$\mathrm{A}$} & 125 & 15,56 & 12,15 \\
& 200 & 22,55 & 17,94 \\
& 250 & 26,15 & 20,60 \\
\hline \multirow{2}{*}{$\mathrm{B}$} & 112 & 14,16 & 10,74 \\
& 125 & 14,50 & 11,52 \\
& 150 & 17,16 & 10,81 \\
\hline \multirow{2}{*}{$\mathrm{D}$} & 112 & 7,10 & 6,26 \\
& 125 & 7,65 & 6,78 \\
& 250 & 11,34 & 10,86 \\
\hline \multirow{2}{*}{$\mathrm{E}$} & 112 & 7,24 & 5,29 \\
& 125 & 7,43 & 5,76 \\
& 150 & 9,50 & 7,36 \\
& 175 & 10,22 & 7,21 \\
\hline \multirow{2}{*}{$\mathrm{F}$} & 125 & 11,13 & 8,20 \\
& 150 & 17,96 & 13,62 \\
\hline
\end{tabular}




\section{Indeks Tekan antar Pabrik (Between Mill)}

Pembahasan ini bertujuan untuk mengetahui apakah keragaman proses antar pabrik mempengaruhi parameter RCT atau tidak. Bila RCT bersifat sebagai karakter bahan, maka seharusnya nilai indeks tekan untuk semua jenis kertas yang diproduksi di pabrik yang berbeda akan sama saja. Tabel 4 memperlihatkan keragaman proses untuk jenis kertas lainer yang sama.

Pada Tebel 4 dapat dilihat bahwa ternyata keragaman data indeks tekan antar pabrik jauh lebih besar dibandingkan dengan keragaman data dalam pabrik yang sama. Pandang data kertas lainer 200 GSM misalnya, keragaman indeks tekan membentang dari nilai 11,49 hingga 27,50 atau berbeda 16,01 pada AM. Sedangkan pada SM perbedaan tersebut adalah 10,01. Data lain pada tabel tersebut tetap memperlihatkan ketidakonstanan nilai indeks tekan.

Tabel 4. Indeks Tekan Lainer antar Pabrik

\begin{tabular}{cccc}
\hline GSM & & \multicolumn{2}{c}{ Indeks Tekan (Nm/g) } \\
\cline { 3 - 4 }$\left(\mathrm{g} / \mathrm{m}^{2}\right)$ & Pabrik & AM & SM \\
\hline \multirow{3}{*}{125} & B & 13,32 & 12,42 \\
& C & 18,43 & 13,79 \\
& D & 13,84 & 10,35 \\
& E & 7,40 & 6,04 \\
& F & 7,42 & 5,56 \\
\hline \multirow{3}{*}{150} & B & 16,91 & 13,91 \\
& C & 20,17 & 14,58 \\
& D & 15,45 & 11,69 \\
& E & 10,05 & 7,31 \\
& F & 9,04 & 7,02 \\
\hline \multirow{3}{*}{200} & A & 27,50 & 15,80 \\
& B & 21,46 & 17,00 \\
& C & 23,81 & 18,38 \\
& D & 18,79 & 15,13 \\
& E & 12,67 & 8,79 \\
& F & 11,49 & 8,37 \\
\hline \multirow{3}{*}{275} & A & 25,37 & 19,25 \\
& C & 27,19 & 20,43 \\
& E & 14,73 & 9,98 \\
\hline
\end{tabular}

Tinjau kertas medium GSM 125 pada Tabel 5. Variasi nilai indeks tekan antar ke-7 pabrik yang berbeda nampak jelas. Pada AM, Pabrik E memberikan nilai indeks tekan terendah 7,43 sedangkan Pabrik A nilainya tertinggi hampir dua kali lipat Pabrik E yaitu 15,56. Seluruh data pada Tabel 5, kembali menunjukkan bahwa nilai Indeks Tekan kertas medium tidak konstan bila dibandingkan antar pabrik yang berbeda.

Variasi nilai indeks tekan antar pabrik sangat dipengaruhi oleh berbagai faktor. Perbedaan minor proses manufaktur dimasing-masing pabrik turut menentukan perbedaan nilai indeks tekan. Mekanisme proses pembentukan lembaran (Fourdrinier, Cylinder, Hybrid Former) juga menyebabkan pola distribusi serat yang berbeda dalam lembaran. Proses pembentukan lembaran tersebut juga melibatkan pilihan tipe wire dan elemen pemisah air yang sangat mempengaruhi struktur lembaran (Jones, 2005).

Tabel 5. Indeks Tekan Medium antar Pabrik

\begin{tabular}{cccc}
\hline \multirow{2}{*}{$\begin{array}{c}\text { GSM } \\
\left(\mathrm{g} / \mathrm{m}^{2}\right)\end{array}$} & Pabrik & \multicolumn{2}{c}{ Indeks Tekan (Nm/g) } \\
\cline { 3 - 4 } 112 & B & 14,16 & 10,74 \\
& $\mathrm{D}$ & 7,10 & 6,26 \\
& $\mathrm{E}$ & 7,24 & 5,29 \\
\hline \multirow{3}{*}{112} & $\mathrm{~A}$ & 15,56 & 12,15 \\
& $\mathrm{~B}$ & 14,50 & 11,52 \\
& $\mathrm{C}$ & 15,53 & 12,41 \\
125 & $\mathrm{D}$ & 7,65 & 6,78 \\
& $\mathrm{E}$ & 7,43 & 5,76 \\
& $\mathrm{~F}$ & 11,13 & 8,20 \\
& $\mathrm{G}$ & 12,03 & 9,28 \\
\hline \multirow{3}{*}{150} & $\mathrm{~B}$ & 17,16 & 10,81 \\
& $\mathrm{E}$ & 9,50 & 7,36 \\
& $\mathrm{~F}$ & 17,96 & 13,62 \\
\hline \multirow{2}{*}{250} & $\mathrm{~A}$ & 26,15 & 20,60 \\
& $\mathrm{D}$ & 11,34 & 10,86 \\
\hline
\end{tabular}

\section{RCT Bukan Karakter Bahan Kertas Lainer dan Medium}

Pembahasan data indeks tekan kertas lainer dan medium di atas, baik dalam pabrik maupun antar pabrik seluruhnya menunjukkan bahwa nilai Indeks Tekan tergantung pada nilai gramatur. Hal ini berarti RCT tidak dapat dikategorikan sebagai karakter bahan. Konsekuensinya, RCT tidak dapat digunakan sebagai parameter mutu kertas lainer dan medium juga tidak bisa digunakan untuk memprediksi mutu KKG. Hal ini mendukung kecenderungan substitusi kertas lainer oleh medium karena produk KKG yang 
demikian tidak mementingkan kekuatan tumpuk (Box Compression Test, BCT), yang berarti juga tidak memerlukan nilai ECT yang tinggi dari $\mathrm{KG}$, dan otomatis pula tidak memerlukan nilai RCT dari lainer dan medium. Sementara itu pengabaian nilai RCT sebagai parameter mutu kertas lainer dan medium oleh produsen dan konverter juga disebabkan karena sulitnya para produsen dan konverter memprediksi mutu $\mathrm{BCT}$ dari nilai RCT.

RCT tidak bisa menjadi karakter bahan karena mengandung kelemahan dari mekanisme pengujiannya. Sekurang-kurangnya ada tiga kelemahan dari cara uji RCT (Markström, 2005) yaitu :

- Bagian atas contoh uji dalam keadaan bebas tidak terjepit klem, sehingga kemungkinan crush pada bagian ini sangat besar

- Sangat sulit mendapatkan kondisi paralel antara pelat penekan dengan contoh uji, sehingga ada kemungkinan gaya tekan tidak terdistribusi secara seragam

- Kemungkinan bukan crush yang terjadi tetapi tekukan pada contoh yang berbentuk cincin

\section{SCT sebagai Alternatif Baru Karakter Bahan Kertas Lainer dan Medium}

Sebagian besar Negara di Eropa sudah tidak menggunakan lagi RCT sejak tahun 1994 sebagai parameter mutu kertas lainer dan medium. Kelemahan metode uji RCT kemudian di atasi dengan membuat area tekan sekecil mungkin. Pada uji RCT area tekan yaitu bagian yang tidak kena jepitan cincin adalah sekitar 6,35 $\mathrm{mm}$. Dengan area sebesar ini, maka
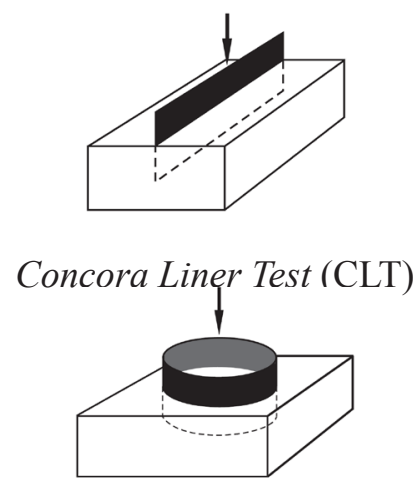

Ring Crush Test (RCT) kemungkinan terjadi tekukan akan lebih besar dibandingkan dengan crush. Oleh karena itu pada metode baru yang telah dikembangkan area tekan ini diperkecil menjadi $0,7 \mathrm{~mm}$, sehingga kemungkinan crush akan lebih besar dibandingkan dengan tekukan. Metode baru ini dikenal dengan nama SCT (Short-span Compression Test).

Laporan hasil analisis menyebutkan bahwa RCT dan SCT adalah dua metode berbeda yang tidak bisa dipertukarkan. Perolehan nilai SCT sekitar 8,7-11,0\% lebih besar dari RCT (Batelka, 2000). Perbedan pokok mekanisme pengujian adalah pada RCT kondisi crush terbentuk akibat lipatan dan tekukan pada kertas gramatur rendah, atau retakan pada kertas gramatur tinggi. Sedangkan pada SCT kondisi crush terbentuk karena ada pembesaran ruang kosong dan putusnya ikatan antar serat. Ditemukan pula bahwa RCT hanya valid pada rentang gramatur yang cukup sempit, sementara SCT valid untuk seluruh rentang gramatur lainer dan medium (Replogle, 2001). Oleh karena itu dikatakan bahwa SCT dapat dipertimbangkan sebagai uji tekan intrinsik untuk lainer dan medium. Pernyataan senada juga mengatakan bahwa SCT mampu mengukur ketahanan tekan murni yaitu ketahanan sebenarnya yang ingin kita ukur. Metode SCT dapat menggantikan metode RCT, dan metode uji tekan yang lain seperti CCT (Corrugated Crush Test) dan CLT (Concora Liner Test) tanpa kekurangan apapun. Ketidaktergantungan nilai SCT pada gramatur kertas juga ditunjukkan dengan baik oleh Marsktrom (2005), sebagaimana ditunjukkan pada Gambar 2. berikut ini. Data hasil penelitian

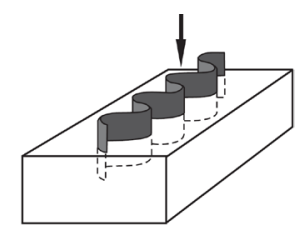

Corrugated Crush Test (CCT)

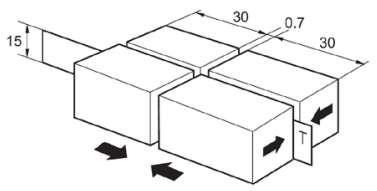

Short-span Crush Test (SCT)

Sumber : (Gullischen, Book 17, 1999)

Gambar 1. Berbagai Metode Uji Tekan Kertas Lainer dan Medium 
penulis ini sebaiknya ditampilkan untuk memperkuat pernyataan bahwa SCT lebih baik.

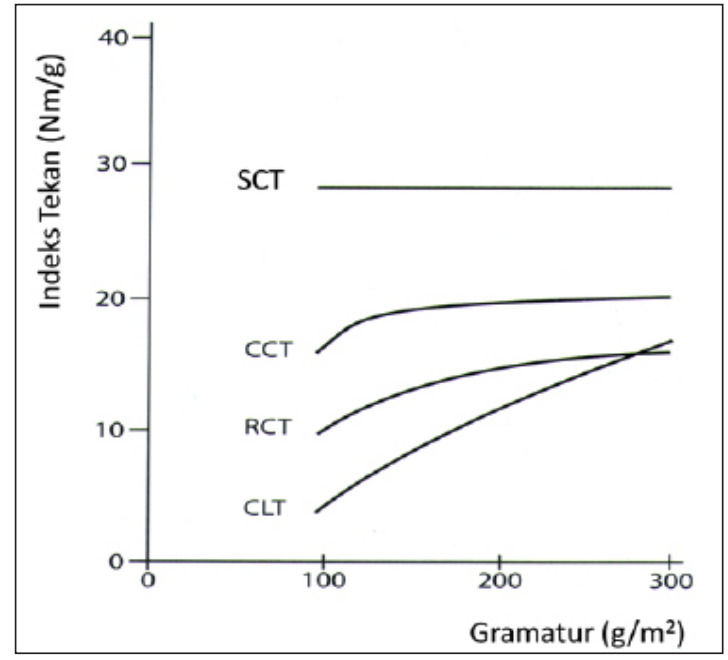

Sumber : (Markströom, 2005)

Gambar 2. Ketergantungan Indeks Tekan terhadap Gramatur

Gambar 2 menunjukkan perbandingan antara 4 metode uji kekuatan tekan untuk kertas lainer dan medium. Pada gambar nampak jelas bahwa parameter CLT dan RCT menunjukkan peningkatan nilai dengan membesarnya gramatur kertas. Hal ini juga menunjukkan bahwa pada gramatur rendah nilai kekuatan tekan sebenarnya akibat penekukan contoh uji (buckling) dan bukan akibat tekanan sebagaimana yang kita kehendaki. Jadi CLT dan RCT tidak mampu mengukur parameter bahan lainer dan medium yang diperlukan. CCT lebih mampu menunjukkan nilai konstan pada berbagai gramatur dibandingkan dengan RCT dan CLT, tetapi besaran nilainya terlalu rendah, sekitar $60 \%$ dari nilai metode STFI. Sementara itu SCT atau metode STFI memperlihatkan nilai yang benar-benar konstan pada berbagai gramatur dan menunjukkan nilai kekuatan tekan murni sebagaimana yang kita maksudkan pada pengujian ini.

\section{KESIMPULAN}

1. Adanyakecenderungan substitusi kertas lainer oleh kertas medium pada KKG menyebabkan terabaikannya sifat ketahanan tumpuk (BCT) dari KKG, yang juga berakibat terabaikannya sifat ketahanan tekan lingkar (RCT) kertas lainer dan medium. Hal ini diperkuat pula oleh kenyataan bahwa korelasi RCT dengan BCT tidak begitu dapat diandalkan.
2. Hasil analisis menunjukkan bahwa parameter RCT tidak dapat ditetapkan sebagai karakteristik intrinsik bahan karena nilainya sangat tergantung pada gramatur dan proses manufaktur. Oleh karena itu, diusulkan digunakan parameter baru yang sudah terbukti kemampuannya menjadi sifat intrinsik bahan, yaitu SCT sebagai pengganti parameter RCT.

\section{UCAPAN TERIMAKASIH}

Penulis mengucapkan terimakasih yang sebesar-besarnya kepada Ibu Rina Masriani yang telah banyak membantu Penulis dalam penyiapan data yang diperlukan.

\section{DAFTAR PUSTAKA}

Anonymous, 2007, Fibrous Materials Use in Fiberboard Manufacture, Technical Bulletin No. 5, Confederation of Paper Industry (CPI), 1-3

Batelka, Joseph J., 2000, The Comparative Response of Ring Crush Test and STFI Short Span Crush Test to Paper Mill Process Variable Changes, Corrugating International, Vol. 2, No. 4, 163 -169

Dimitrov, K., 2010, Relationship Between the ECT-Strength of Corrugated Board and the Compression Strength of Liner and Fluting Medium Papers, 20-24, disertasi, Faculty of Engineering - University of Pretoria, Pretoria, South Africa

Gullischen, J., Paulapuro, H., 1999, Papermaking Science and Technology - Book 16 Paper PhysicsSub-Chapter 6.2, Fapet Oy, Helsinki

Gullischen, J., Paulapuro, H., 1999, Papermaking Science and Technology-Book 17 Pulp and Paper Testing Sub-Chapter 10.2.3, Fapet Oy, Helsinki

Hidayat, T., Masriani, R., Asid, D.A., 2008, Prediksi Dampak Substitusi Kertas Lainer Oleh Kertas Medium Pada Karton Gelombang Menggunakan Persamaan Empiris, Berita Selulosa, Vol. 43, No. 1, 19-28

Hidayat, T., 2009, Pembuktian Empiris Indeks Retak Sebagai Parameter Bebas Gramatur, Berita Selulosa, Vol. 44, No. 1, 11-16

Holik, H., 2006, Paper and Board Manufacturing, in Herbert Holik (Ed.) Handbook of Paper and Board, Wiley-VCH $\mathrm{GmbH} \& \mathrm{Co}$, Weinheim, 320-321

Jones, R., 2005, Minor Machine Adjustments Help Mills Meet Latest Containerboard Standards, WEAVEXX, 1-4 
Khaki, F., Samariha, A., Kasmani, J.E., 2011, Neutral Sulfite Semi-Chemical Pulping of Bagasse, World Applied Science Journal, Vol. 13, No. 1, 85-89

Laakso, O., Rintamäki, T., 2001, Production and Converting of Corrugated Board, 139140, Finnish Corrugated Board Association, Lahti, Finland

Markström, H., 2005, Testing Methods and Instruments for Corrugated Board, 32-34, AB Lorentzen Wettre, Kista, Sweden

Popil, R.E., 2010, A New Model for Converting Short Span Compression with other Measurements to Ring Crush, Georgia Tech - IPST, 1-6
Replogle, J.W., 2001, Ring Crush Vs. STFI for Testing Compression, Corrugating International, Vol. 3, No. 3, 15-18

Samariha, A., Nemati, M., Hemmasi, A.H., 2011, Effects of Refining Intensity on Characteristics of Pulp Produced from Bagasse through Neutral Sulfite SemiChemical Pulping, American-Eurasian Journal of Agriculture and Environmental Science, Vol. 11, No. 1, 10-14 